\title{
ANALYSIS OF COOPERATIVE UNIONS' DEVELOPMENT CASE STUDY: POLAND
}

Cooperative unions in Poland are self-aid communities acting on the market of financial services. They gather people connected by the same working place or membership in the same community or professional group, who save together and lend money one another. They play an important economic role in Poland because of the fact that they are servicing people who because of their unfavourable or unstable financial condition could not be clients of commercial banks, and in this way would be denied the access to certain financial services, mainly to credits. In the presented article the quick development of the cooperative unions in Poland is presented.

\section{Introduction}

The history of Polish cooperative unions goes back to the inter-wars period when the people's banks and saving-banks were founded, aiming at the mutual help, self-management and economic democracy. They were based on the ideas of Friedrich Wilhelm Raiffaisen - the creator of financial cooperatives, in the mid 19th century in Germany. Nowadays, similar financial institutions called credit unions operate in 79 countries, gathering 118 million of people. They are supported by the philosophy of cooperation and by the basic values like: equality, members' capital and mutual aid. The motto of the American movement is: not for profit, not for charity, but for service.

\section{Cooperative unions in Poland}

Restoration of the cooperative unions in Poland started after 1989. They are the self-aid communities acting on the market of financial services, they gather people connected by the same working place or the membership in the same community or professional group, who save together and lend money one another. They operate on the basis of the Act of Cooperative Unions' Law and the Act of the Law of Cooperatives. They are supervised by the National Council, whose basic aim is ensuring the financial stability of all cooperative unions and security of the savings collected there. National Council in Poland is the member of World Council of Credit Unions, Inc. (WOCCU) ${ }^{1)}$ and International Co-operative Alliance (ICA) ${ }^{2}$.

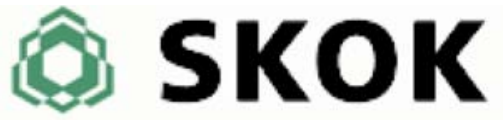

Fig. 1. Logo of cooperative unions in Poland

Source: National Council of Cooperative Unions in Poland.

Cooperative unions in Poland play an important economic role, because of the fact, that they are servicing people, who because of their unfavourable or unstable financial condition could not be clients of commercial banks, and in this way would be denied the access to certain financial services, mainly to credits (see SWOT analysis - Table 1).

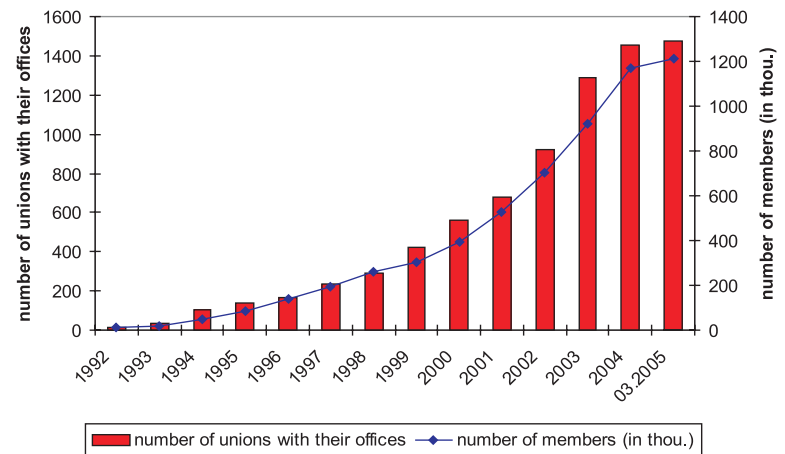

Fig. 2. Number of cooperative unions with their offices and the number of members (in thou.) in 1992-2005

Source: National Council of Cooperative Unions in Poland.

\footnotetext{
* Joanna Bednarz Ph. D.

University of Gdansk, Institute of International Business, Armii Krajowej 119/121, 80-824 Sopot, tel./fax +48 58 551-58-82, E-mail: j.bednarz@ek.univ.gda.pl

1) World Council of Credit Unions, Inc. (WOCCU) is the world's leading advocate, platform for knowledge exchange and development agency for credit unions. Members of the World Council include regional and national credit union associations, cooperative associations and business service organisations. Today, credit unions in 84 countries provide more than 123 million people worldwide with an opportunity to grow through access to safe savings, affordable credit and the chance for a better tomorrow; http://www.woccu.org

2) The International Co-operative Alliance is an independent, non-governmental association which unites, represents and serves organisations in all sectors of activity including agriculture, banking, energy, industry, insurance, fisheries, housing, tourism and consumer co-operatives. ICA has more than 230 member organisations from over 100 countries, representing more than 760 million individuals worldwide; http://www.ica.coop/ica/ica
} 


\begin{tabular}{|c|c|}
\hline $\begin{array}{ll}\text { Strengths } \\
\end{array}$ & Weaknesses \\
\hline $\begin{array}{l}\text { - stable position on the market } \\
\text { - good quality of the offered services (PN-ISO } 9002 \text { certificate } \\
\text { for rendering financial services) } \\
\text { - knowing the members and their needs within the local society } \\
\text { - high level of customers' service } \\
\text { - activities done promptly and reliably } \\
\text { - confidence, long tradition, members' feeling of integrity } \\
\text { - quick increase of the number of new members } \\
\text { - qualified personnel and professional management } \\
\text { - a broad network of branches in the whole country } \\
\text { - more flexible response to the market changes following from } \\
\text { a limited range of activities }\end{array}$ & $\begin{array}{l}\text { - high unit costs following from a relatively narrow scale of activity } \\
\text { - relatively low proper funds } \\
\text { - high costs of acquiring the membership } \\
\text { - principles of membership difficult to understand by a potential } \\
\text { member } \\
\text { - a broad organisation structure - lack of good contacts of the } \\
\text { branches with the head office } \\
\text { - bureaucracy - lack of professionally elaborated documents } \\
\text { - marketing located in the head office } \\
\text { - poorly developed banking technology }\end{array}$ \\
\hline Opportunities & $\begin{array}{cc}\text { Threats } \\
\end{array}$ \\
\hline $\begin{array}{l}\text { - possibility of offering services at more advantageous condi- } \\
\text { tions than those on the market } \\
\text { - a gradual economic growth manifested with a great number of } \\
\text { financial undertakings and with the need for capital } \\
\text { - new products offered to the retail customers, such as internet } \\
\text { banking } \\
\text { - a gradual development of the segment of enterprises } \\
\text { - increase of the volume of the given credits }\end{array}$ & $\begin{array}{l}\text { - subordination of the cashiers' desks to the bank supervision } \\
\text { and introduction of the obligatory provision } \\
\text { - dependence of the acquired financial results on the policy of } \\
\text { the National Council } \\
\text { - a great competition of institutions of the similar character } \\
\text { - attraction of commercial banks and their services } \\
\text { - high rate of unemployment leading to resignation from the ser- } \\
\text { vices }\end{array}$ \\
\hline
\end{tabular}

Source: own study.

After 13 years of cooperative unions' activity in Poland they have over 1.2 million of members and the network of their branches is the biggest one among the financial institutions offering financial services to people (Fig. 2). In March 2005 unions' assets exceeded PLN 4,5 billion and their members borrowed over PLN 2.9 billion (Table 2$)$.

During last 6 years the number of cooperative unions decreased from 200 down to 83, mainly because of mergers (Figure 3). Right now, the 10 biggest unions serve ca. $70 \%$ of all clients. The biggest of them is the F. Stefczyk Union, having over 200 offices and gathering ca. 400 thousand of retail clients, which means more than the CitibankHandlowy ${ }^{3)}$. The reasons of mergers is mainly the tendency to strengthen of the market position of banks and financial conditions of the overtaken unions. Moreover, the growing requirements of the members, pertaining mainly to taking advantage of the bank services (like ATM), or to a bigger number of offices cause that the merging divisions decrease the risk connected with the concentration of servicing of a homogeneous group of clients, and they lower the costs of their operations.

In spite of the fact that the cooperative unions are going to develop the network of their offices, on the other hand they work intensively on introducing the electronic methods of access to the
Cooperative unions in Poland - assets, deposits and Table 2. loans (in millions of PLN) in 1992-2005

\begin{tabular}{|c|c|c|c|}
\hline Years & $\begin{array}{c}\text { Assets } \\
\text { (in millions } \\
\text { of PLN) }\end{array}$ & $\begin{array}{c}\text { Deposits } \\
\text { (in millions } \\
\text { PLN) }\end{array}$ & $\begin{array}{c}\text { Loans } \\
\text { (in millions } \\
\text { of PLN) }\end{array}$ \\
\hline 1992 & 4 & 4 & 3 \\
\hline 1993 & 11 & 9 & 9 \\
\hline 1994 & 35 & 29 & 26 \\
\hline 1995 & 101 & 92 & 83 \\
\hline 1996 & 219 & 190 & 161 \\
\hline 1997 & 368 & 313 & 281 \\
\hline 1998 & 590 & 528 & 412 \\
\hline 1999 & 883 & 740 & 668 \\
\hline 2000 & 1199 & 995 & 866 \\
\hline 2001 & 1752 & 1558 & 1236 \\
\hline 2002 & 2455 & 2254 & 1660 \\
\hline 2003 & 3344 & 3112 & 2213 \\
\hline 2004 & 4233 & 3938 & 2857 \\
\hline 03.2005 & 4506 & 4212 & 2940 \\
\hline
\end{tabular}

Source: National Council of Cooperative Unions in Poland.

\footnotetext{
${ }^{3)}$ A. Myczkowska, SKOK. Coraz więcej kas znika z rynku, „Rzeczpospolita”, 2 February 2005.
} 
money - such as: by telephone and through the Internet. It has been assumed, that until the end of the present year, the electronic facilities will have been available in the biggest unions.

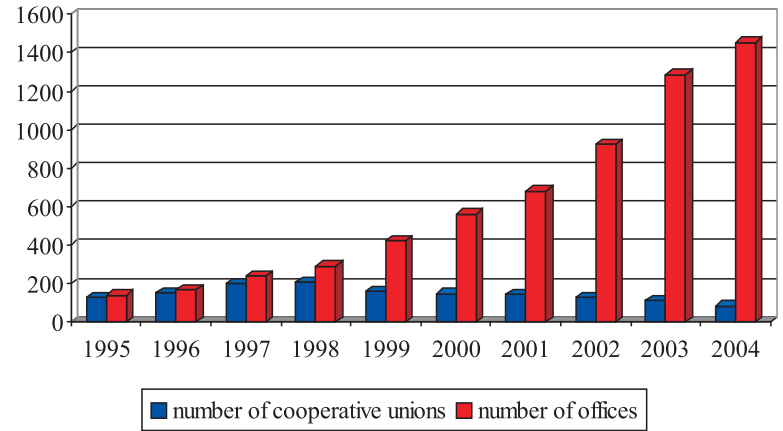

Figure 3. Number of cooperative unions and their offices in 1995-2004 Source: National Council of Cooperative Unions in Poland

\section{Products offered by the cooperative unions in Poland}

A quick development of the cooperative unions follows also from the fact of a very fast developing offer of financial products. The unions are proposing to their clients long-term programmes of systematic savings, and the collected savings are the security for the loans and credits. Since the beginning, the cooperative unions offer the simplest bank products i.e. loans and deposits. In the scope of savings, they propose á vista accounts, fixed-term deposit accounts, rentier deposit accounts, current accounts, company accounts for the members conducting the economic activity and special systematic saving deposit accounts: for Christmas, holidays and health ${ }^{4)}$. Credit services also encompass a range of products: short and long term credits and "immediate loans" popular among of the members (until the nearest payment of salary)

Since autumn 2002, when cooperative unions were connected to the new ELIXIR system of inter banking settlements, they offer the settlement bank products (encompassing current accounts and VISA Electron payment cards, see Figure 4).

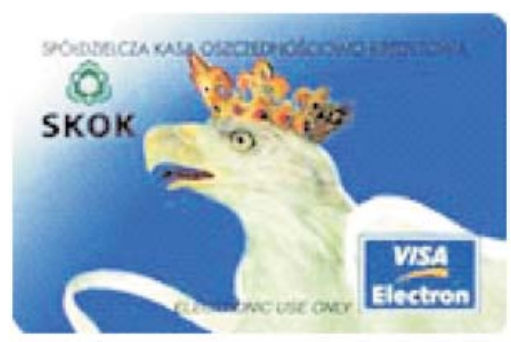

Fig. 4. Design of VISA Electron payment card Source: National Council of Cooperative Unions in Poland.

The cooperative unions offer to their clients the estate, personal and life insurance, including group life insurance with additional options, and since 1 September 2004 - also Individual Pension Accounts. Moreover the Open Investment Fund of the Financial Market offers the possibility of depositing members' financial means in securities issued or guaranteed by the Treasury, National Bank of Poland and the units of local governments.

Cooperative unions in Poland offer their products under more advantageous conditions when compared to commercial banks. Interests on deposits are of about 2 percentage points higher than in banks and on loans and credits - correspondingly lower.

\section{Conclusion}

The Chairman of the Board of WOCCU, Robert McVeigh estimates, those Polish cooperative unions based on the experience of American, Canadian and Irish ones could offer in a very short time, financial services at the highest level. It is estimated that the cooperative unions in Poland would still develop very dynamically and in 10 years, their members would constitute ca. $40 \%$ of the adult Poles ${ }^{5}$.

Nowadays, the development of cooperative unions in Ukraine, Belarus, Russia, Moldova and Romania is planned. This time, it is Poland that is to take part in consulting and help for these unions on the new markets.

\section{References:}

[1] MYCZKOWSKA A.: SKOK. More and more cooperative unions disappear from the market (in Polish), Rzeczpospolita, 2 February 2005.

[2] Reports of National Council of Cooperative Unions in Poland, www.skok.pl

[3] SKOK. The control of Polish Central Bank in Poland does not always have the desired effect (in Polish), Rzeczpospolita, 5-6 February 2005.

[4] The International Co-operative Alliance, http://www.ica.coop/ica/ica

[5] World Council of Credit Unions, Inc., http://www.woccu.org

\footnotetext{
4) For more information see also: www.skok.pl, 14.08.2005.

5) SKOK. Nadzór banku centralnego nie zawsze ma dobry skutek, „Rzeczpospolita”, 5-6 February 2005.
} 